\title{
Evidence for the Presynaptic Localization of Opiate Binding Sites on Striatal Efferent Fibers
}

\author{
B. ABOU-KHALIL, A. B. YOUNG and J. B. PENNEY
}

University of Michigan, Department of Neurology, Ann Arbor, MI 48109 (U.S.A.)

(Accepted March 27th, 1984)

Key words: opiates - receptors — striatum - globus pallidus - presynaptic receptors - D-Ala-D-Leu-enkephalin - naloxone

\begin{abstract}
Using quantitative receptor autoradiography, $\left[{ }^{3} \mathrm{H}\right] \mathrm{D}$-Ala-b-Leu-enkephalin (DADL) and $\left[{ }^{3} \mathrm{H}\right]$ naloxonc binding were studied in rat striatum and striatal projection areas (globus pallidus (GP) and substantia nigra pars reticulata ( $\mathrm{SN}_{\mathrm{f}}$ )) after unilateral striatal kainic acid lesions. $\left[{ }^{3} \mathrm{H}\right] \mathrm{DADL}$ and $\left[{ }^{3} \mathrm{H}\right]$ naloxone binding were each examined by two methods. Initially, [ $\left.{ }^{3} \mathrm{H}\right] \mathrm{D}$ ADL binding was performed in $50 \mathrm{mM}$ Tris- $\mathrm{HCl}(\mathrm{pH} 7.4), 30 \mathrm{mM} \mathrm{NaCl} .3 \mathrm{mM}$ manganese acetate and $2 \mu \mathrm{M} \mathrm{GTP}:\left[{ }^{3} \mathrm{H}\right] \mathrm{naloxone}$ binding was carried out in $50 \mathrm{mM}$ Tris- $\mathrm{HCl}(\mathrm{pH} 7.4)$ and $100 \mathrm{mM} \mathrm{NaCl}$. Subsequent studies were carried out in $150 \mathrm{mM}$ Tris-HCl (pH 7.4) and either [ ${ }^{3} \mathrm{H}$ ]DADL plus $500 \mathrm{nM}$ morphiceptin (to block [ $\left.{ }^{3} \mathrm{H}\right] \mathrm{DADL}$ binding to mu receptors) or [ $\left.{ }^{3} \mathrm{H}\right]$ naloxone plus $10 \mathrm{nM}$ delta receptor peptide (to block $\left[{ }^{3} \mathrm{H}\right]$ naloxone binding to delta receptors). At one and eight weeks in the lesioned striatum. [ $\left.{ }^{3} \mathrm{H}\right] \mathrm{DADL}$ binding was reduced by $70 \%$ and $82 \%$. respectively, when compared to the control side. $\left[{ }^{3} \mathrm{H}\right] \mathrm{N}$ aloxone binding was reduced by $35 \%$ and $20 \%$. In $G \mathrm{P}$ and $\mathrm{SN}$, $\left[{ }^{3} \mathrm{H}\right] \mathrm{DADL}$ binding was reduced by $31 \%$ and $41 \%$. respectively, at one week and $27 \%$ and $26 \%$ at eight weeks. [ $\left.{ }^{3} \mathrm{H}\right] \mathrm{Naloxone}$ binding was reduced $19 \%$ in GP at eight weeks. A parsimonious explanation of these results is that opiate binding sites are located on presynaptic terminals of striatal efferent fibers to globus pallidus and substantia nigra pars reticulata as well as on local striatal axon collaterals. Since opiate peptides have recently been found to coexist with GABA in some striatal neurons, opiate peptides may play at role in striatal function by controlling GABA release from striatal efferent fibers. It is possible that pallidal and nigral opiate binding could be utilized as a marker for striatal terminals.
\end{abstract}

\section{INTRODLCTION}

Neurons and presynaptic terminals in the striatum contain high concentrations of enkephalin-like immunoreactivity $12,13.18 .27,48,53$. There are also high levels of enkephalin in the lateral globus pallidus (GP) $x .9,11-13,27,4 \times, 53$ and some is present in the substantia nigra pars reticulata $\left(\mathrm{SN}_{\mathrm{r}}\right)^{12,13}$. Immunohistochemical studies suggest that the enkephalin in GP and $\mathrm{SN}_{r}$ is located primarily in presynaptic terminals ${ }^{2.44}$. The peptide is released from these terminals after electrical stimulation of caudate nucleus ${ }^{24}$. After striatal lesions or deafferentation, enkephalin levels in GP and $\mathrm{SN}_{\mathrm{r}}$ fall markedly $8,9,11,13.48$. Taken together. this evidence suggests that there is a major enkephalinergic pathway from the striatum to the GP and a lesser pathway to $\mathrm{SNr}$.

Despite this evidence for an enkephalinergic stria- topallidal and striatonigral pathway in rat, only low levels of both mu and delta opiate receptors have been found in the GP and $\mathrm{SN}_{\mathrm{r}} 1 \cdot 16 \cdot 17.23,41.51$. In contrast, high levels of $\mathrm{mu}$ and delta opiate receptors have been observed in striatum $1.16 .17,21,22.41 .51$. Some striatal opiate receptors appear to be localized on the axon terminals of dopaminergic and serotonergic striatal afferent fibers ${ }^{33,39}$ and may function to control dopamine and serotonin release. However, the role of opiates and opiate receptors in striatal function and output is largely unknown. We have measured opiate receptors in the striatum and the primary striatal projection areas after destruction of striatal neurons with kanic acid.

\section{METHODS}

Male Sprague-Dawley rats weighing $150-200 \mathrm{~g}$

Correspondence: J. B. Penney, Jr.. Neuroscience Building, 1103 East Huron Street, Ann Arbor. MI 48109. U.S.A 
were anesthetized with $7 \mathrm{mg} / \mathrm{kg}$ xylazine and $100 \mathrm{mg} / \mathrm{kg}$ ketamine (i.p.). Kainic acid lesions were made according to our previously described meth$\operatorname{od}^{38.42}$. Kainic acid (Sigma), 0.1 M, adjusted to pH 7.0 with $\mathrm{HCl}$, was applied iontophoretically into the right striatum of these rats by passing negative current $(5 \mu \mathrm{A})$ in $500 \mathrm{~ms}$ on $/ 500 \mathrm{~ms}$ off pulses for 5 min through a glass micropipette tip with an inner diameter of $50 \mu \mathrm{m}$. Angled injections from $30^{\circ}$ forward of vertical passing through prefrontal cortex were made using a David Kopf small animal stereotaxic device. The pipette tip was placed $2.0 \mathrm{~mm}$ anterior, $3.0 \mathrm{~mm}$ lateral and $4.2 \mathrm{~mm}$ ventral to Bregma with the incisor bar $5 \mathrm{~mm}$ above the ear bars (AP $+8.0 \mathrm{~mm}, \mathrm{ML}+3.0 \mathrm{~mm}, \mathrm{DV}+1.0 \mathrm{~mm}$ ) according to the atlas of König and Klippel-28.

In initial studies, rats were decapitated 7-10 days after the striatal lesion, the brains were quickly removed, mounted on microtome chucks with Lipshaw frozen embedding medium, and frozen at $-20^{\circ} \mathrm{C}$. Twenty $\mu \mathrm{m}$ thick coronal sections of the brains were cut in a cryostat (Lipshaw) and thaw-mounted onto detergent cleaned, gelatin-coated microscope slides. Slides were kept frozen at $-20^{\circ} \mathrm{C}$ overnight. The next day, serial sections through the lesion, globus pallidus and substantia nigra were washed twice for 5 min each in cold buffer and then blown dry in a stream of cool air. Sections were incubated with [ $\left.{ }^{3} \mathrm{H}\right]$ naloxone $(1-5 \mathrm{nM})$ in $50 \mathrm{mM}$ Tris $\mathrm{HCl}(\mathrm{pH} 7.4)$ and $100 \mathrm{mM} \mathrm{NaCl}$ at $4{ }^{\circ} \mathrm{C}$ for $1 \mathrm{~h}$ to preferentially label mu opiate receptors, or with [ $\left.{ }^{3} \mathrm{H}\right] \mathrm{D}-\mathrm{Ala}$-D-Leuenkephalin (DADL) $(1-8 \mathrm{nM})$ in $50 \mathrm{mM}$ Tris $\mathrm{HCl}$, $30 \mathrm{mM} \mathrm{NaCl}, 3 \mathrm{mM}$ manganese acetate and $2 \mu \mathrm{M}$ GTP at $20^{\circ} \mathrm{C}$ for $30 \mathrm{~min}$ according to the method of Lewis et al.29. The slides were then given six 20)-s washes with $50 \mathrm{mM}$ Tris $\mathrm{HCl}, \mathrm{pH} 7.4$ at $4{ }^{\circ} \mathrm{C}$, dried. mounted in an X-ray cassette with 6-14 calibrated standards and tritium-sensitive film (Ultrofilm $3 \mathrm{H}$, LKB). The film was exposed for $3-6$ weeks at $4{ }^{\circ} \mathrm{C}$ and developed in D19, for $3 \mathrm{~min}$ at $20^{\circ} \mathrm{C}$, fixed, washed and dried.

Films were analyzed using a spot densitometer ${ }^{38}$. Eight to ten measurements of optical density were made over each region of interest, as well as each standard and film background. The optical densities (ODs) produced by regions of interest were compared to the ODs produced by the standards and the film background. A computer-generated polynomial regression analysis of the standard curve was used to calculate the amount of radioactivity in a given areat of interest. The total amount of ligand bound to each area of interest was calculated from the specific activity of the ligand and the amount of radioactivity in the tissue. Specific binding in each area of interest was calculated by subtracting from the wotal binding the amount of ligand bound to the region in sections incubated with excess $\left(1 \times 10^{-6} \mathrm{M}\right)$ etorphine (defined as non-specific binding). The number $\left(B_{\max }\right)$ and affinity $\left(K_{d}\right)$ of receptors were calculated by EadicHofstee analyses of dose-response curves from autoradiographs of sections taken through the region of interest.

At the concentrations examined $(1-8 \mathrm{nM})$, substantial variations in specific binding were observed between various brain regions. Although non-specific binding was relatively uniform throughout the tissue section, the specific to non-specific ratios varied considerably. In the striatum, the "nonpatch' areas had a specific to non-specific binding ratio of $3: 1$ for $\left[{ }^{3} \mathrm{H}\right]$ naloxone and $10: 1$ for $\left[{ }^{3} \mathrm{H}\right] \mathrm{DADL}$; in globus pallidus, the ratio was $3.4: 1$ for $\left[{ }^{3} \mathrm{H}\right]$ naloxone binding and $5: 1$ for [ ${ }^{3} \mathrm{H} \mid \mathrm{DADL}$; in substantia nigra pars reticulata, the ratio was $4.5: 1$ for $[3 \mathrm{H}]$ naloxone binding and 3.5:1 for [3H]DADL.

Selected sections were postfixed over paraformaldehyde vapors and stained with cresyl violet to assure that the lesions did not extend into the globus pallidus. Sections were also analyzed by computer-assisted methods ${ }^{37}$ to measure the approximate size of the striatal lesions.

The incubation conditions described above label mu and delta receptors relatively selectively and the various ion and nucleotide concentrations were used to maximize the number of binding sites labeled. It was also considered important to study opiate receptors using drugs which would preferentially block delta receptor binding during $\left[{ }^{3} \mathrm{H}\right]$ naloxone binding studies and mu receptor binding during $\left[{ }^{3} \mathrm{H}\right] \mathrm{DADL}$ binding studies. These assays used different buffer and incubation conditions from the first assays. It was ascertained that $10 \mathrm{nM}$ delta receptor peptide ${ }^{14}$ would block $80-90 \%$ of [ $\left.{ }^{3} \mathrm{H}\right] \mathrm{DADL}$, binding but only a $20-30 \%$ of $\left[{ }^{3} \mathrm{H}\right]$ naloxone binding. Likewise, it was determined that a $500 \mathrm{nM}$ concentration of morphiceptin $^{6}$ would block $80-90 \%$ of [3H]naloxone binding but only $10-20 \%$ of [3H]DADL binding. 
Additional animals were lesioned with kainate as described above, allowed to survive for 8 weeks, the animals decapitated and the brains removed, sectioned and prepared for autoradiography. Sections were incubated in $1-6 \mathrm{nM}\left[{ }^{3} \mathrm{H}\right]$ naloxone, $10 \mathrm{nM}$ delta receptor peptide and $150 \mathrm{mM}$ Tris $\mathrm{HCl}$ buffer ( $\mathrm{pH} 7.4$ ) for $1 \mathrm{~h}$ at $4{ }^{\circ} \mathrm{C}$. Alternate sections to those exposed to $\left[{ }^{3} \mathrm{H}\right]$ naloxone were incubated in $1-6 \mathrm{nM}$
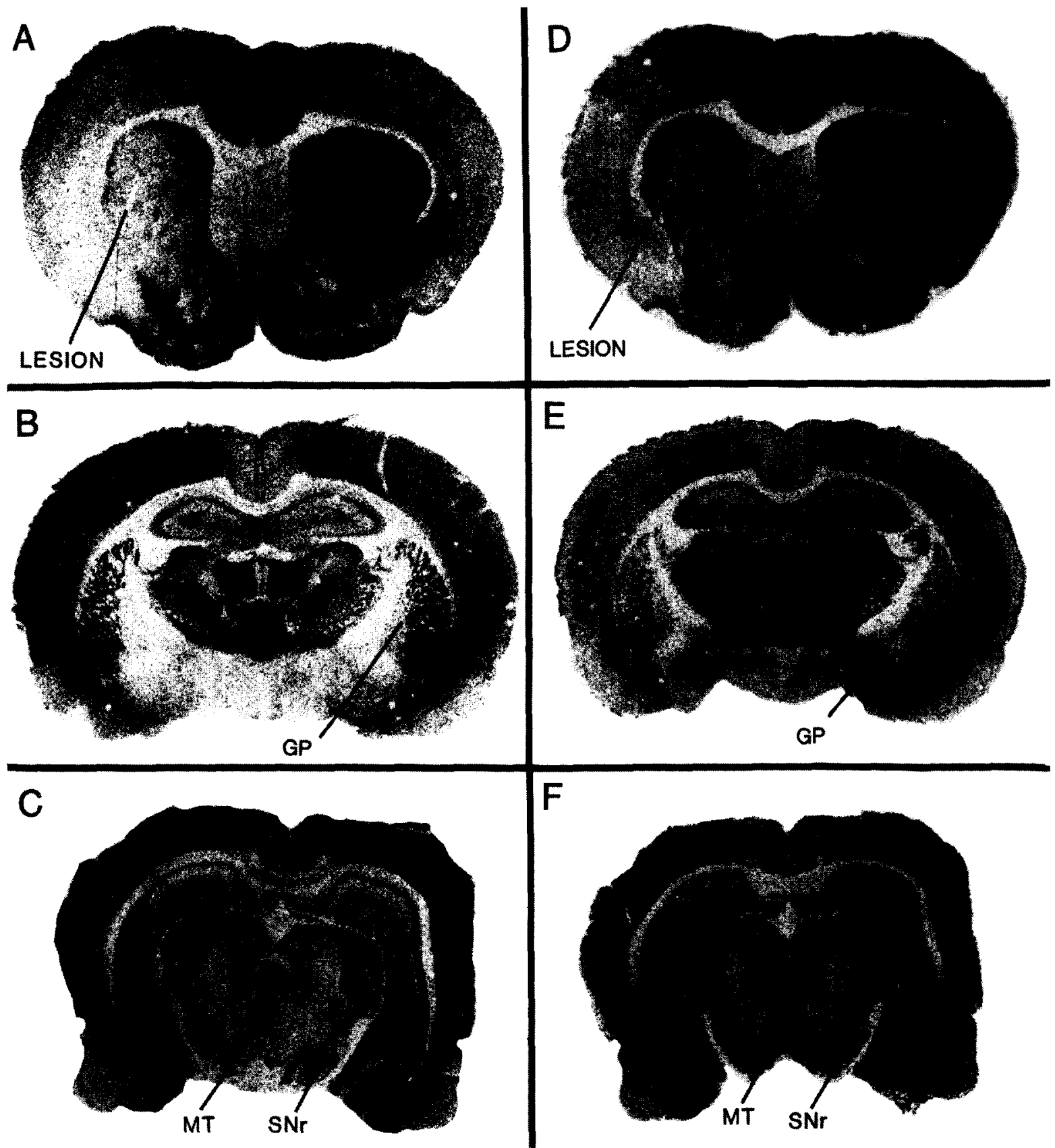

Fig. 1. Opiate receptor binding one week after a striatal kainate lesion. A-C: [ $\left.{ }^{3} \mathrm{H}\right]-\mathrm{D}-\mathrm{Ala}-\mathrm{D}-\mathrm{L}$ eu-cnkephalin binding to sections through the striatal lesion, lateral globus pallidus and substantia nigra, respectively. Binding was performed in the presence of $5 \mathrm{nM}$ [ ${ }^{3} \mathrm{H}$ ]DADL. $50 \mathrm{mM}$ Tris- $\mathrm{HCl}$ (pH 7.4), $30 \mathrm{mM} \mathrm{NaCl}, 3 \mathrm{mM}$ manganese acetate and $2 . / \mathrm{M} \mathrm{GTP}$; D-F: [ $\left.{ }^{3} \mathrm{H}\right]$ naloxone binding to brain sections was performed in the presence of $5 \mathrm{nM}\left[{ }^{3} \mathrm{H}\right]$ naloxone. $50 \mathrm{mM}$ Tris- $\mathrm{HCl}(\mathrm{pH} 7.4)$ and $100 \mathrm{mM} \mathrm{NaCl}$. D. E and F are sections serially adjacent to $A, B$ and $C$, respectively. Each of these photographs was printed individually to optimize the appearance of receptors at each level. Thus, quantitative densitometric comparisons cannot be extrapolated directly from the visual images. GP. Globus pallidus; MT. Medial terminal nucleus of the accessory optic tract: SNr, Substantia nigra pars reticulata. 
[ ${ }^{3} \mathrm{H}$ ]DADL, $500 \mathrm{nM}$ morphiceptin and $150 \mathrm{mM}$ Tris $\mathrm{HCl}$ buffer $\left(\mathrm{pH} \mathrm{7.4)}\right.$ for $1 \mathrm{~h}$ at $4{ }^{\circ} \mathrm{C}$. After incubation, slides were washed 6 times in cold $50 \mathrm{mM}$ Tris $\mathrm{HCl}(\mathrm{pH} 7.4)$ for $20 \mathrm{~s}$ each wash. The slides were then dried in a stream of cool air and exposed to U1trofilm ${ }^{3} \mathrm{H}$ (LKB) for 6 weeks. Receptor numbers and affinities were then determined as above.

\section{RESULTS}

Autoradiograms of $\left[{ }^{3} \mathrm{H}\right] \mathrm{DADL}$ and $\left[{ }^{3} \mathrm{H}\right]$ naloxone binding determined by both methods are shown in Figs. 1 and 3. The distribution of binding in cortex and striatum was quite distinctive depending upon the ligand used. This was true independent of the incubation procedure. Nevertheless, the different incubation conditions brought out differences in receptor distribution. [ $\left.{ }^{3} \mathrm{H}\right] \mathrm{DADL}$ binding was highest in layers II, III and VI of cortex using either technique. In striatum, $\left[{ }^{3} \mathrm{H}\right] \mathrm{DADL}$ binding was relatively uniform but, using the initial incubation conditions, dense 'patches' of binding were readily observed similar to that seen with $\left[{ }^{3} \mathrm{H}\right]$ naloxone binding. 'Patches' were virtually absent when [3H]DADL binding was performed in the presence of morphiceptin. Cortical $\left[{ }^{3} \mathrm{H}\right]$ naloxone binding was highest in intermediate layers of cortex. In striatum, dense patches of opiate receptors with lesser concentrations in the back- ground were evident. For both ligands, binding was low in globus pallidus and substantia nigra pars reticulata. A consistent feature in the midbrain with both ligands was a dense strip of binding in the medial nucleus of the accessory optic tract along the medial aspect of nigra. In this study, neither the opiate receptors in patches, nor in the medial nucleus were systematically analyzed because there were not enough serial sections for dose-response curves to be reliable in these areas.

Inspection of the autoradiograms from the first set of animals one week after lesioning revealed a loss of [ $\left.{ }^{3} \mathrm{H}\right] \mathrm{DADL}$ binding in the striatum, GP and $\mathrm{SN}_{\mathrm{r}}$ ipsilateral to the lesion (Fig. $1 \mathrm{~A}-\mathrm{C}$ ). [3H]Naloxone binding appeared to be decreased in the lesion but not at distant sites (Fig. 1D-F). These observations were confirmed by quantitative densitometry (see Table I). Area measurements of the lesion size in the striatum at multiple levels indicated that, on average. $40 \%$ of the head of the caudate was destroyed by the lesion.

Receptor binding in each animal was analyzed by Eadie-Hofstee plots of binding at 4-6 concentrations of each ligand in sections through each structure. In the initial experiment, there were significant reductions in the number of $\left[{ }^{3} \mathrm{H}\right] \mathrm{DADL}$ binding sites in the lesion $(67 \%$ decrease, $P<0.001)$ and the ipsilateral GP $(30 \%$ decrease, $P<0.01)$ and $\mathrm{SN}_{\mathrm{r}}(41 \%$ de-

\section{TABLE 1}

Opiate receptors one week after unilateral striatal lesions

Binding was carried out as described in the text using the first set of incubation conditions, values represent the average of $6-9$ animals \pm S.E.M.

\begin{tabular}{|c|c|c|c|c|c|c|}
\hline \multirow[t]{2}{*}{ Region } & \multicolumn{3}{|c|}{$[H] D A D L$ binding } & \multicolumn{3}{|c|}{$[3 \mathrm{H}]$ naloxone binding } \\
\hline & $\begin{array}{l}B_{\max }(f \operatorname{mol} / m g \\
\text { protein })\end{array}$ & $K_{d}(n M)$ & $\begin{array}{l}\text { Lesioned } \\
\text { control } \\
(\times I 00)\end{array}$ & $\begin{array}{l}B_{\max }(\mathrm{fmol} / \mathrm{mg} \\
\text { protein })\end{array}$ & $K_{d}(n M)$ & $\begin{array}{l}\text { Lesioned } \\
\text { control } \\
(\times 100)\end{array}$ \\
\hline \multicolumn{7}{|c|}{ Striatum $(n=9)$} \\
\hline Lesioned & $211 \pm 43^{* *}$ & $3.4 \pm 0.7$ & 30 & $214 \pm 10^{*}$ & $1.2 \pm 0.3$ & 05 \\
\hline Control & $701 \pm 109$ & $3.7 \pm 0.4$ & & $331 \pm 30$ & $1.5 \pm 0.4$ & \\
\hline \multicolumn{7}{|c|}{ Globus Pallidus $(n=9)$} \\
\hline Lesioned & $108 \pm 11^{*}$ & $2.3 \pm 1.0$ & 69 & $218 \pm 20$ & $1.9 \pm 0.6$ & 80 \\
\hline Control & $157 \pm 10$ & $2.0 \pm 0.7$ & & $273 \pm 43$ & $1.7 \pm 0.4$ & \\
\hline \multicolumn{7}{|c|}{ Substantia Nigra $(n=6)$} \\
\hline Lesioned & $213 \pm 54^{* *}$ & $4.2 \pm 1.2$ & 59 & $361 \pm 100$ & $2.3 \pm 11$ & 89 \\
\hline Control & $363 \pm 99$ & $4.3 \pm 0.6$ & & $406 \pm 68$ & $2.1 \pm 1.2$ & \\
\hline
\end{tabular}



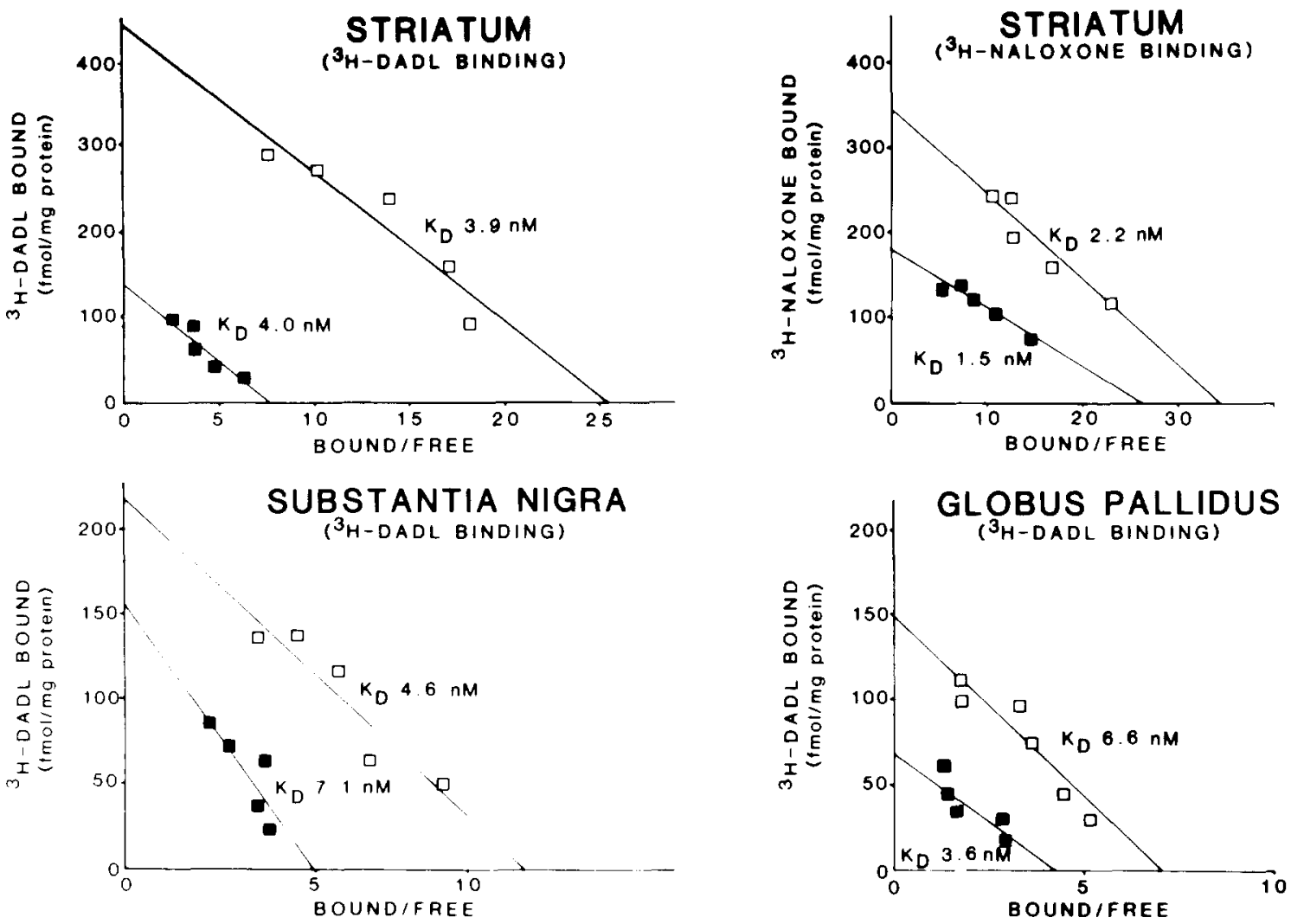

Fig. 2. Representative Eadie-Hofstee plots of $\left[{ }^{3} \mathrm{H}\right]-\mathrm{D}-\mathrm{Al}$ - $-\mathrm{D}-\mathrm{Leu}$-enkephalin (DADL) binding in various regions of rat brains one week after unilateral striatal kainate lesions. Serial sections of rat brain were incubated with $1-8 \mathrm{nM}\left[{ }^{3} \mathrm{H}\right] \mathrm{DADL}$ or $\mathrm{I}-5 \mathrm{nM}\left[{ }^{3} \mathrm{H}\right] \mathrm{na}$ loxone as described in the methods. Points represent the mean of 8 densitometric readings taken from the area of interest on the autoradiogram. Closed squares represent values from the lesioned side and open squares represent values from the unlesioned side.

crease, $P<0.01$ ) (Fig. 2. Table I). The only significant reduction in $\left[{ }^{3} \mathrm{H}\right]$ naloxone binding was a $36 \%$ decrease $(P<0.01)$ in the lesion. This decrease was significantly less than the decrease in $\left[{ }^{3} \mathrm{H}\right] \mathrm{DADL}$ binding in the same areas. There were no significant changes in the affinity of binding for either ligand in any of the areas measured.

Using incubation procedures which included either delta receptor peptide or morphiceptin in assays of tissue sections from animals surviving 8 weeks postlesion, changes in binding similar to those seen acutely ( 1 week) after striatal lesions were seen in striatum, globus pallidus and nigra (Fig. 3, Table II). Overall $\left[{ }^{3} \mathrm{H}\right]$ naloxone and $\left[{ }^{3} \mathrm{H}\right] \mathrm{DADL}$ binding using this second incubation procedure was less than with the first assay (see Tables I and II) because of the different ionic and nucleotide conditions and because of the cross inhibition of mu and delta sites. Again, the lesion size was about $40 \%$ of the head of the caudate. $\left[{ }^{3} \mathrm{H}\right]$ DADL binding was decreased $82 \%(P<0.001)$ at the site of the lesion in striatum, $27 \%(P<0.01)$ in globus pallidus and $26 \%(P<0.02)$ in substantia nigra pars reticulata (Fig. $3 \mathrm{~A}-\mathrm{C}$ ). $\left[{ }^{3} \mathrm{H}\right]$ Naloxone binding was decreased by $20 \%(P<0.02)$ in striatum, 19\% $(P<0.05)$ in globus pallidus and non-significantly by $27 \%$ in substantia nigra pars reticulata (Fig. 3D-F). In striatum, $\left[{ }^{3} \mathrm{H}\right]$ naloxone binding in the 'patches' was decreased dramatically at 8 weeks (but not quantified). This change in the patches was not observed at one week post lesion with either incubation method.

\section{DISCUSSION}

Striatal kainate lesions caused decreases in opiate binding locally in the striatum and distantly in the globus pallidus and substantia nigra of rats. The magnitude of the receptor changes in the striatal projec- 


\section{TABLE Il}

Opiate receptors eight weeks after unilateral striatal lesions

Assays were as described in the text using the second set of incubation conditions. Values are the average $\pm S . E . M$. The number of animals used for [ $\left.{ }^{3} \mathrm{H}\right] \mathrm{DADL}$ binding in striatum, GP and $\mathrm{SN}_{\mathrm{r}}$ equaled 6,6 and 5 , respectively. The number of animals used for $\left[{ }^{3} \mathrm{H} \mid \mathrm{nal}\right.$ axone binding in striatum, GP and $\mathrm{SN}_{\mathrm{r}}$ equaled 9,9 and 8 . respectively.

\begin{tabular}{|c|c|c|c|c|c|c|}
\hline \multirow[t]{2}{*}{ Region } & \multicolumn{3}{|c|}{ IHIDADL binding } & \multicolumn{3}{|c|}{$I^{3} H /$ naloxone binding } \\
\hline & $\begin{array}{l}B_{\max }(\mathrm{fmol} / \mathrm{mg} \\
\text { protein) }\end{array}$ & $K_{d}(n M)$ & $\begin{array}{l}\text { Lesioned } \\
\text { control } \\
(\times 100)\end{array}$ & $\begin{array}{l}B_{\max }(\text { fmolimg } \\
\text { protein) }\end{array}$ & $K_{d l}(n M)$ & $\begin{array}{l}\text { Lesioned } \\
\text { control } \\
(\times 100)\end{array}$ \\
\hline \multicolumn{7}{|l|}{ Striatum } \\
\hline Lesioned & $35 \pm 6^{11}$ & $1.2 \pm 0.3$ & & $74 \pm 8$ & $2.1 \pm 0.3$ & 80 \\
\hline Control & $195 \pm 24$ & $2.2 \pm 0.4$ & 18 & $92 \pm 9$ & $2.0 \pm 0.3$ & \\
\hline \multicolumn{7}{|c|}{ Globus Pallidus } \\
\hline Lesioned & $29 \pm 2^{b}$ & $1.4 \pm 0.2$ & & $55 \pm 9^{d}$ & $2.3 \pm 04$ & 81 \\
\hline Control & $40 \pm 2$ & $2.1 \pm 0.6$ & 73 & $68 \pm 10$ & $2.4+1.2$ & \\
\hline \multicolumn{7}{|c|}{ Substantia Nigra } \\
\hline Lesioned & $56 \pm 10$ & $2.8 \pm 0.8$ & 74 & $101 \pm 16$ & $2.9 \pm 0.6$ & 73 \\
\hline Control & $76 \pm 12$ & $3.1 \pm 0.7$ & & $139 \pm 28$ & $4.2 \pm 1.3$ & \\
\hline
\end{tabular}

tion areas averaged about $30 \%$, consistent with the size of the striatal lesion (which was about $40 \%$ of the body of the caudate). These changes were similar to those found for known presynaptic markers of striatal terminals such as levels of GABA ${ }^{34}$, glutamic acid decarboxylase $\mathrm{e}^{4,14}$ substance- $\mathrm{P}^{4,25}$ and enkephalin itself $8,9,11,48$. These results differ from those that have been found for markers of postsynaptic receptors after striatal lesions ${ }^{19,30.38,46.47,50}$. In these studies, there were local decreases in GABA, benzodiazepine, muscarinic cholinergic and dopamine receptors while there were distant increases in GABA and benzodiazepine but not acetylcholine receptors ${ }^{38,52}$. The latter results were consistent with the development of postsynaptic receptor supersensitivity.

In this study, the findings suggested that opiate binding sites in globus pallidus and substantia nigra existed on striatofugal presynaptic axon terminals: The results were consistent with neurophysiological evidence that enkephalins acted presynaptically on axon terminals to inhibit the release of other neurotransmitters ${ }^{31.32}$ and with anatomical studies showing the presynaptic localization of opiate receptors in striatum and other regions ${ }^{1,3,33,39,44}$. It might be argued that the local loss of opiate binding seen after striatal lesions was consistent with a postsynaptic location of these binding sites in the striatum. It should be remembered, however, that striatal neurons have a vast number of local recurrent axon collaterals 2,40 and local release of enkephalin in the striatum has been demonstrated after striatal stimulation ${ }^{21}$. Thus, the most parsimonius explanation for the results found in this study is that a substantial portion of the opiate binding sites in the striatum, pallidum and nigra are on presynaptic terminals of striatal neurons. If this proves true, measurement of opiate binding might serve as a marker for striatal cell loss in animal studies and in human studies using positron emission tomography.

The difference in the binding of [3H]DADL and $\left[{ }^{3} \mathrm{H}\right]$ naloxone in the lesioned animals was intriguing. Neither [ $\left.{ }^{3} \mathrm{H}\right]$ DADL binding nor $\left[{ }^{3} \mathrm{H}\right]$ naloxone binding was absolutely selective for delta and mu receptors and with each ligand there was a certain amount of labeling of other receptor subtypes 5 . Two different binding assays were used to enhance selective labeling to delta and mu receptors. In each case, the changes in opiate binding after striatal lesions were more significant under conditions which favored binding to delta opiate receptors. An exception to 

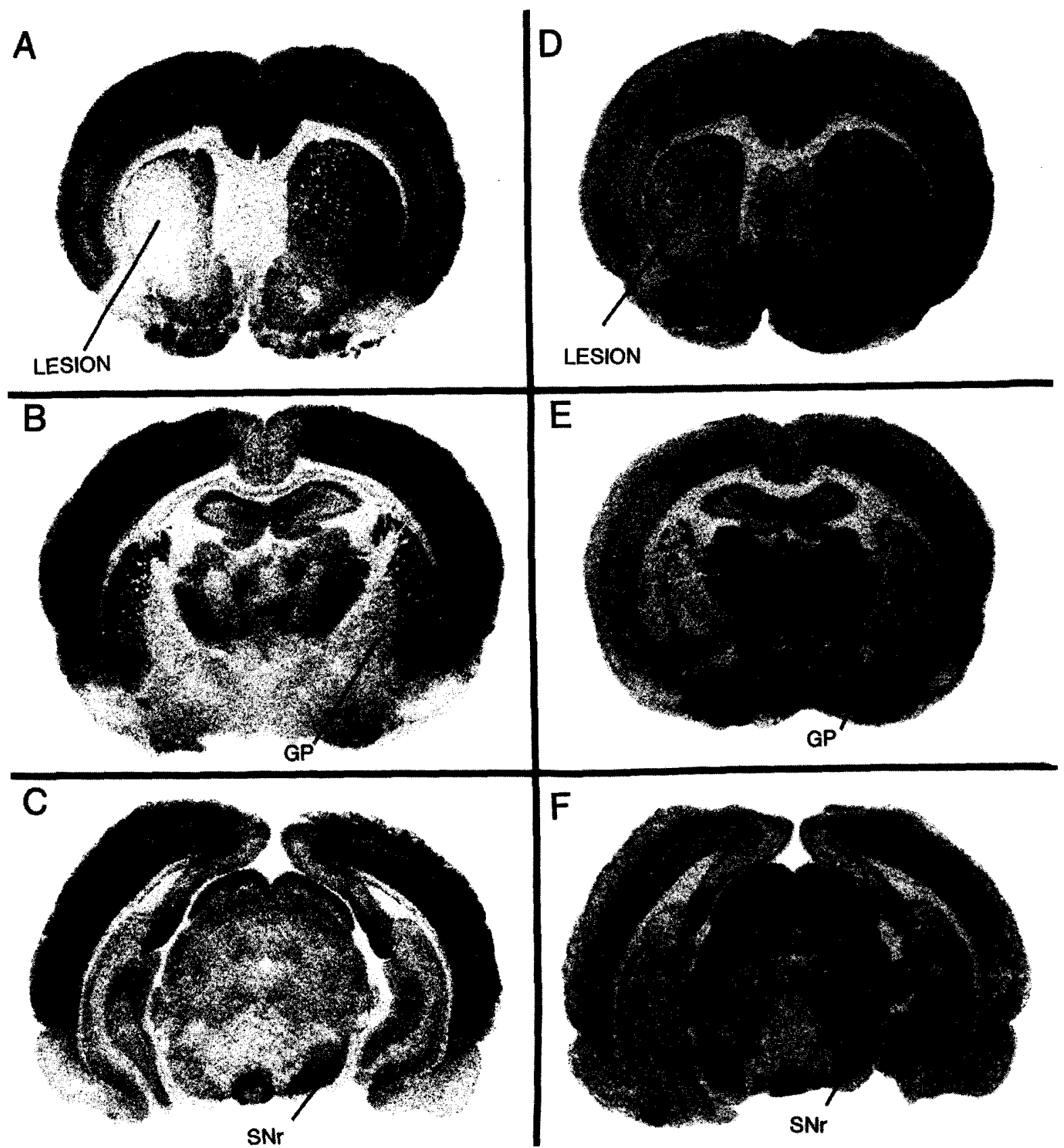

Fig. 3. Opiate receptor binding 8 weeks after a striatal kainate lesion. A-C: $\left[{ }^{3} \mathrm{H}\right]-\mathrm{D}$-Ala-D-Leu-enkephalin binding to sections through the striatal lesion, globus pallidus and substantia nigra, respectively. Binding was performed in the presence of $4 \mathrm{nM}\left[{ }^{3} \mathrm{H}\right] \mathrm{DADL}$. $150 \mathrm{mM}$ Tris $\mathrm{HCl}(\mathrm{pH} 7.4)$ and $500 \mathrm{nM}$ morphiceptin. D-F: $\left[{ }^{3} \mathrm{H}\right]$ naloxone binding to sections serially adjacent to those in $\mathrm{A}-\mathrm{C}$. Binding was performed in the presence of $5 \mathrm{nM}\left[{ }^{3} \mathrm{H}\right]$ naloxone, $150 \mathrm{mM}$ Tris $\mathrm{HCl}(\mathrm{pH} 7.4)$ and $10 \mathrm{nM}$ delta receptor peptide. Each of these photographs was printed individually to optimize the appearance of receptors at each level. Thus, quantitative densitometric comparisons can not be extrapolated directly from the visual images. Abbreviations as in Fig. 1.

this observation was the long term changes seen in $\left[{ }^{3} \mathrm{H}\right]$ naloxone binding to the 'patches'. In this study, it was not ascertained whether the changes in binding to the 'patches' involved postsynaptic receptor changes or long term degeneration of striatal afferent fibers. Likewise, the possibility of receptor loss due to transynaptic dendritic degeneration was not evaluated. Transsynaptic degeneration of postsynaptic 
dendrites has been observed after decortications and nigrostriatal lesions ${ }^{20}$. Similar transsynaptic degeneration could account for some of the binding changes seen in GP and SNr. Also, it should be noted that not all striatal opiate receptors are thought to be on the axon terminals of striatal neurons. Other investigators have shown that some striatal opiate binding sites are on serotonin and dopamine striatal afferent terminals ${ }^{33,39}$. Kappa receptor binding ${ }^{7,15}$ also was not assessed in this study but would be of interest since a subset of striatal neurons demonstrate dynorphin-like immunoreactivity ${ }^{49}$ and levels of dynorphin are high in substantia nigra pars reticulata ${ }^{27,45,49}$.

The role of opiate peptides in striatal function and striatal output is unclear. A large percentage of striatal neurons show opiate-like immunoreactivity ${ }^{12}$. A similarly large proportion of striatal neurons (approximately $70 \%$ ) demonstrate GAD-like immunoreactivity indicating a high concentration of GABA

\section{REFERENCES}

1 Atweh, S. F. and Kuhar, M. J., Autoradiographic localization of opiate receptors in rat brain. III. The telencephalon, Brain Research, 134 (1977) 393-405.

2 Bishop, G. A., Chang, H. T. and Kitai, S. T., Morphological and physiological properties of neostriatal neurons -- an intracellular horseradish peroxidase study in the rat, $\mathrm{Neu}$ roscience, 7 (1982) 179-191.

3 Bowen, W. D., Pert, C. B. and Pert, A., Nigral hydroxydopamine lesions equally decrease mu-opiate and deltaopiate binding to striatal patches-further evidence for a conformationally malleable type-1 opiate receptor, Life. Sci., 31 (1982) 1679-1682.

4 Brownstein, M. J., Mroz, E. A., Tappaz, M. L. and Leeman, S. E., On the origin of substance $P$ and glutamic acid decarboxylase (GAD) in the substantia nigra, Brain Research, 135 (1977) 315-323.

5 Chang, K.-J. and Cuatrecasas, P., Multiple opiate receptors: enkephalins and morphine bind to receptors of different specificity, J. Biol. Chem., 254 (1979) 2610-2618.

6 Chang, K.-J., Killian, A., Hazum, E. and Cuatrecasas, P.. Morphiceptin $\left(\mathrm{NH}_{4}\right.$-Tyr-Pro-Phe-Pro-CONH$\left.{ }_{2}\right)$ : a potent and specific agonist for morphine $(\mu)$ receptors, Science, 212 (1981) 75-77.

7 Chavkin, C., James, I. F. and Goldstein, A., Dynorphin is a specific endogenous ligand of the $x$ opioid receptor, Science, 215 (1982) 413-415.

8 Correa, F. M. A., Innis, R. B., Hester, L. D. and Snyder, S. H., Diffuse enkephalin innervation from caudate to globus pallidus, Neurosci. Lett., 25 (1981) 63-68.

9 Cuello, A. C. and Paxinos, G., Evidence for a long leu-enkephalin striatopallidal pathway in rat brain, Nature (Lond.), 271 (1978) 178-180.

10 David, M., Moisand, C., Meunier, J.-C., Morgat, J.-L., neurons in striatum ${ }^{36}$. Recently, immunocytochemical double-labeling studies have demonstrated a coexistence of opiate-like and GAD-like immunoreactivity ${ }^{36}$. The coexistence of opiate peptides in GABA neurons and the presynaptic localization of opiate receptors on striatal efferent terminals suggest that striatal opiates may function in part to control GABA release presynaptically. The presynaptic control of GABA release may be one mechanism by which opiates affect striatal function ${ }^{i 5}$.

\section{ACKNOWLEDGEMENT}

Supported by USPHS Grants NS 00464 (J.B.P.) and NS 00420 (A.B.Y.) and by a grant from the McKnight Foundation. We wish to thank Zane Hollingsworth and Rick Kontos for excellent technical assistance and Deb DeSmyther for secretarial assistance.

Gacel, G. and Roques, B. P., ['H]Tyr-D-Ser-Gly-Phe-LeuThr: A specific probe for the $\delta$ opiate receptor subtype in brain membranes, Europ. I. Pharmacol., 78 (1982) 385-387.

11 Del Fiacco, M., Paxinos, G. and Cuello, A. C., Neostriatal enkephalin-immunoreactive neurons project to the globus pallidus, Brain Research, 231 (1982) 1-17

12 DiFiglia, M., Aronin, N. and Martin; J. B., Light and electron microscopic localization of immunoreactive leu-enkephalin in the monkey basal ganglia, J. Neuresci, 2 (1982) 303-320

13 Emson, P. C., Arregui, A., Clement. J. V., Sandberg, B. E. B. and Rossor, M., Regional distribution of methionineenkephalin and substance P-like immunoreactivity in normal human brain and in Huntington's disease, Brain Research, 199 (1980) 147-160.

14 Fonnum, F., Gottesfeld, Z. and Grofoya, I., Distribution of glutamate decarboxylase, choline acetyltransferase and aromatic amino acid decarboxylase in the basal ganglia of normal and operated rats. Evidence for striatopallidal, striatoentopeduncular and striatonigral GABAergic fibers, Brain Research, 143 (1978) 125-138.

15 Foote, R. W. and Maurer, R., Autoradiographic locatization of opiate $x$-receptors in the guinea-pig brain. Europ. J. Pharmacol., 85 (1983) 99-103.

16 Geary, W. A. and Wooten, G. F., Quantitative film autoradiography of opiate agonist and antagonist binding in rat brain, J. Pharmacol. Exp. Ther., 225 (1983) 234 240.

17 Goodman, R. R., Snyder, S. H., Kuhar, M. J., Young and Scott. W.. Differentiation of delta and mu opiate receptor localizations by light microscopic autoradiography, Proc. nat. Acad. Science, 77 (1980) 6239-6243.

18 Graybiel, A. M., Ragsdale, C.W. Yoneoka, E. S and Elde, R. P., An immunohistochemical study of enkephalins and other neuropeptides in the striatum of the cat with evi- 
dence that opiate peptides are arranged to form mosaic patterns in register with the striosomal compartments visible by acetylcholinesterase staining, Neuroscience, 6 (1981) $377-397$

19 Guidotti, A.. Gale, K., Suria. A. and Toffano, G., Biochemical evidence for two classes of GABA receptors in rat brain. Brain Research, 172 (1979) 566-571.

20 Hattori, T. and Fibiger, H. C., On the use of lesions of afferents to localize neurotransmitter receptor sites in the striatum. Brain Research, 238 (1982) 245-250.

21 Henderson. G., Hughes, J. and Kosterlitz, H. W.. In vitro release of leu- and met-enkephalin from the corpus striatum, Nature (Lond.), 271 (1978) 677-679

22 Herkenham. M. and Pert. C. B.. In vitro autoradiography of opiate receptors in rat brain suggests loci of "opiatergic' pathways. Proc. nat. Acad. Sci. U.S.A., 77 (1980) $5532-5536$.

23 Herkenham, M. and Pert. C. B., Light microscopic localization of brain opiate receptors: a general autoradiographic method which preserves tissue quality, J. Neurosci., 2 (1982) 1129-1149.

24 lversen, L. L.. Iversen. S. D., Bloom, F. E.. Vargo, T. and Guillemin. R. Release of enkephalin from rat globus pallidus in vitro, Nature (Lond.), 271 (1978) 679-681.

25 Jessel, T. M., Emson, P. C., Paxinos, C. and Cuello, A. C.. Topographical projection of substance-P and GABA pathways in the striatopallidonigral system: a biochemical and immunohistochemical study. Brain Research, 152 (1978) $487-498$.

26 Johnson. P. J.. Sar. M. and Stumpf, W. E., A topographic localization of enkephalin on the dopamine neurons of the rat substantia nigra and ventral tegmental area demonstrated by combined histofluorescence-immunocytochemistry, Brain Research, 194 (1980) 566-571.

27 Khachaturian. H. Lewis. M. E., Hollt. V. and Watson. S. $\mathrm{J}$. Telencephalic enkephalinergic systems in the rat brain. J. Neurosci., 3 (1983) 844-855

28 Konig, J. F. R. and Klippel. R. A., The Rat Brain. Krieger. Huntington. N. Y.. 1963.

29 Lewis, M. E., Mishkin. M.. Bragin, E., Brown, R. M., Pert. C. B and Pert, A., Opiate receptor gradients in monkey cerebral cortex: Correspondence with sensory processing hierarchies. Science. 211 (1981) 1166-1169.

30 Lloyd, K. G.. Dreksler, S. and Bird, E. D., Alterations in ?H-GABA binding in Huntington's chorea, Life Sci., 21 (1977) $747-754$

31 Macdonald, R. L. and Nelson, P. G., Specific-opiate-induced depression of transmitter release from dorsal root ganglion cells in culture. Science, 199 (1978) 1499-1451.

32 Mudgc. A. W. Leeman. S. E. and Fischbach, G. D.. Enkephalin inhibits release of substance-P from sensory neurons in culture and decreases action potential duration. Proc. Nat. Acad. Sci. (U.S.A.), 76 (1979) 526-530.

33 Murrin, L. C. Coyle. J. T. and Kuhar. M. J., Striatal opiate receptors: Pre- and postsynaptic localization, Life Sci. 27 (1980) $1175-1183$.

34 Nagy. J. Carter, D. and Fibiger, H., Anterior striatal projections to the globus pallidus, entopeduncular nucleus and substantia nigra in the rat: the GABA connection. Brain Research. $158(1978) 15-29$

35 Napier. T. C.. Pirch. J. H. and Strahlendorf, H. K.. Naloxone antagonizes striatally-induced suppression of globus pallidus unit activity, Neuroscience, 9 (1983) 53-59.

36 Oertel, W. H. Riethmuller, O.. Mugnaini, E.. Schmechel, D. E., Weindl. A.. Gramsch, C. and Herz, A., Opioid pep- tide-like immunoreactivity localized in GABAergic neurons of rat neostriatum and central amygdaloid nucleus, Life Sci, in press.

37 Pan, H. S., Dauth. G. W., Young, A. B. and Penney, J. B., Computer-assisted estimates of lesion sizes and shrinkage in denervated areas from receptor autoradiograms using a digitizing tablet, Neurosci. Lett., in press.

38 Pan, H. S., Frey, K. A., Young, A. B. and Penney. J. B., Changes in $\left[{ }^{3} \mathrm{H}\right]$ muscimol binding in substantia nigra, entopeduncular nucleus, globus pallidus, and thalamus after striatal lesions as demonstrated by quantitative receptor autoradiography, J. Neurosci., 3(1983) 1189-1198.

39 Parenti, M., Tirone, F., Olgiati. V. R. and Groppetti. A. Presence of opiate receptors on striatal serotonergic nerve terminals, Brain Research, 280 (1983) 317-322.

40 Park, M. R. . Lighthall, J. W. and Kitai, S. T., Recurrent inhibition in the rat neostriatum. Brain Research, 194 (1980) $359-369$.

41 Pearson, J., Brandeis, L., Simon. E. and Hiller, J., Radioautography of binding of tritiated diprenorphine to opiate receptors in the rat, Life Sci., 26 (1980) 1047-1052.

42 Penney, J. B. and Young, A. B.. GABA as the pallidothalamic neurotransmitter: implications for basal ganglia function. Brain Research. 207 (1981) 195-194.

43 Penney, J. B., Young. A. B., Walker, F. O. and Shoulson, I. Quantitative autoradiography of opiate receptors in Hintington's disease, Neurology, Suppl. 1. 34 (1984) 154

44 Pollard, H., Llorens-Cortes. C. and Schwartz. J. C., Enkephalin receptors on dopaminergic neurones in rat striatum. Nature (Lond.), 268 (1977) 745-747.

45 Robbins, K. C., Devare, S. G.. Reddy, E. P. and Aaronson, S. A., Comparison of the distribution of dynorphin systems and enkephalin systems in brain, Science, 218 (1982) $1134-1136$.

46 Reisine, T. D., Beaumont. K.. Bird. E. D.. Spokes, E. and Yamamura, H. 1., Huntington's disease: Alterations in neurotransmitter receptor binding in the human brain. Adv. Neurol.. 23 (1979) 717-726.

47 Reisinc. T. D., Wastek, G. J., Speth, R. C., Bird, E. D. and Yamamura, H. I.. Alterations in the benzodiazepine receptor of Huntington's diseased human brains. Brain Research, 165 (1979) 183-187

48 Sar. M., Stumpl, W. E., Miller, R. J.. Chang, K,-J. and Cuatrecasas. P.. Immunohistochemical tocalization of enkephalin in rat brain and spinal cord. $J$. comp. Neurol., 182 (1978) 17-38.

49 Vincent. S. R.. Hokfelt, T. Christensson, I. and Terenius. L., Dynorphin-immunoreactive neurons in the central nervous system of the rat, Neurosci. Lett., 33 (1982) 185-190.

50 Waddington, J. L. and Cross. A. J., Characterization of denervation supersensitivity in the striatonigral GABA pathway of the kainic acid-lesioned rat and in Huntington's disease. Brain Res. Bull., $5(1980) 825-828$.

51 Wamsley, J. K., Zarbin. M. A.. Young. W. S. and Kuhar, M. J., Distribution of opiate receptors in the monkey brain - an autoradiographic study, Neuroscience, 7 (1982) $595-613$.

52 Wastek, G. J.. Stern. I. Z., Johnson. P. C. and Yamamura, H. I.. Huntington's disease: Regional alteration in muscarinic cholinergic receptor binding in human brain. Life Sci., 19(1976) 1033-1040).

53 Yang. H. Y.. Hong. J. S. and Costa, E., Regional distribution of leu- and met-enkephalin in rat brain. Neurophamacology, 16(1977) 303-307. 